\title{
Öğretmen Adaylarının Mesleğinde Öz Yeterliğin Tutum ve Motivasyona Etkisi: Eğitim Fakültesi ile Pedagojik Formasyon Eğitimi Alan Öğretmen Adayları Üzerine Bir Araştırma
}

The Effectiveness of Self Adequacy To Attitude and Motivation In The Job of Teacher Candidates: A Research on Pedogogical Formation Education Candidates and the Faculty Of Education Candidates

\section{Meral Bektaş \& Şerife Karagöz}

Sosyal Bilimler Meslek Yüksekokulu, Mehmet Akif Ersoy Üniversitesi, Burdur, Türkiye

\section{Özet}

Eğitim sisteminin başarısının verimliliğinin arttırılmasında, toplumun geleceğinin biçimlendirilmesinde ve dönüştürülmesinde ihtiyacı olan nitelikte insan gücünün yetiştirilebilmesi için öğretmenlere olan gereksinim her geçen gün artmaktadır. Öğretmen adaylarının mesleğe yönelik özyeterlik, motivasyon ve tutumlarının öğretmenlik mesleğindeki önemi yadsınamaz bir gerçektir. Bu araştırma Akdeniz Üniversitesi Eğitim Fakültesi 4. sınıfta öğrenim görmekte olan öğretmen adayları ile Eğitim Fakültesinde Pedagojik Formasyon eğitimi almakta olan öğretmen adaylarının özyeterliğinin tutum ve motivasyon üzerine etkisini irdelemek amacıyla yapılmıştır. Araştırmada veri toplama aracı olarak anket formu kullanılmıştır. Araştırma kapsamında 400 anket verisi analizlere dâhil edilmiş olup; $\% 66^{\prime}$ sının kadın öğretmen adayları \% 44'ünü erkek öğretmen adayları oluşturmaktadır. Öğretmen adaylarının özyeterliğinin tutum ve motivasyon üzerine etkisini tespit etmek amacıyla regresyon analizi kullanılmıştır. Araştırma bulgularına göre; özyeterlik ölçeğinin alt boyutları (başlama, yılmama, sürdürme) ile motivasyon ölçeğinin alt boyutları (başarı, ilişki, güç) üzerinde bir etkiye sahipken tutum üzerinde bir etkiye sahip olmadığı saptanmıştır.

Anahtar Kelimeler: Özyeterlik, Motivasyon, Tutum, Pedagojik Formasyon, Öğretmenlik. Jel Kodu: M10

\section{Abstract}

The need for teachers to increase the efficiency of the success of the education system and the ability to raise the quality of human resources in the form and transformation of the society's future is increasing day by day. The importance of teacher candidates' selfefficacy, motivation and attitudes in teaching profession is an undeniable fact. This research was carried out to investigate the effects of self-efficacy on attitudes and motivation of teacher candidates who are studying in the 4th grade of the Akdeniz University Faculty of Education and teacher candidates who are studying the Pedagogical Formation in the Faculty of Education. Survey form was used as data collection tool in the research. 400 survey data were included in the analyzes; $66 \%$ of female teacher candidates and $44 \%$ of male teacher candidates. Regression analysis was used to determine the effect of self-efficacy of teacher candidates on attitude and motivation. According to research findings; it was found that the self - efficacy scale had no effect on the sub - dimensions (initiation, non - aggression, maintenance) and motivation scale subscales (success, relationship, power).

Key words: Self-efficacy, Motivation, Attitude, Pedagogical Formation, Teaching.

Gel Code: M10

CONTACT : Meral Bektaş, mbektas@mehmetakif.edu.tr, ORCID ID: orcid.org/0000-0002-1616-8065; Şerife Karagöz, krgz_srf@hotmail.com, ORCID ID: orcid.org/0000-0002-2542-1026

Geliş Tarihi \& First Received : 15.08.2017

Kabul Tarihi \& Accepted $\quad$ : 20.09.2017 


\section{Giriş}

Toplumda sağlıklı, bilimin parlak 1şı̆̆ına kavuşmuş, çağdaş bireyler yetiştirebilmenin temelindeki en önemli unsur eğitim sistemidir. Bu sistemin etkin ve verimli bir şekilde, istenilen sonucu verecek niteliği sağlaması gerekmektedir. Eğitim sisteminde temel unsurun öğretmenlerden oluştuğu yadsınamaz bir gerçektir. Sistemin kalitesini artırmak için öğretmenlerin nicelik ve niteliklerinin arttırılması gerekmektedir. Bilgi, sistemin ayrılmaz ve en önemli parçasıdır. Bilginin kümülatif olarak ilerlemesi, bilginin gelecek nesillere aktarılmasında ve toplumsal yapının kurulmasında baş rolü oynayan öğretmenlerin önemini arttırmaktadır. Süreçte birçok faktör olmasına rağmen; öğretmenler rehber olma özelliğinden dolayı kuşkusuz diğer faktörlere göre süreç içinde daha etkilidir. Günümüzde meslek tanımlamaları yapılırken bu meslekleri yapmak için gerekli kişilik özellikleri de belirlenmektedir. Kişilerin yapacakları mesleğin gerektirdiği kişilik özelliklerine sahip olmaları gerekmektedir. Özellikle, eğitim ve eğitimin en önemli yapı taşlarından biri olan öğretmenlerin de, öğretmenlik mesleğinin gerektirdiği kişilik özelliklerine sahip olması gerekmektedir (Yeşilyurt, 2011, s. 72).

Eğitim sisteminin önemli ve vazgeçilemez unsuru olan öğretmenler, toplumu zihinsel, fiziksel, psikolojik, davranışsal, sosyal ve daha birçok yönleriyle etkileme gücüne sahip mesleklerin başında gelmektedir (Üstüner, 2006, s. 110). Nitelikli öğretmen yetiştirme ile ilgili sorunsallar güncelliğini koruyan konular arasındadır. Çünkü eğitim sisteminin temeli ile doğrudan ilişki halinde olan öğretmenler, bütün sistemin etkililik ve verimliliğinde büyük önem arz etmektedir (Castetter, 1986, s. 221).

Her mesleğin olduğu gibi öğretmenlik mesleğinin de, mesleğin doğru bir şekilde icra edilebilmesi için, gerektirdiği bazı kişilik özellikleri vardır. Öğretmenlik, çok yönlü gelişmeyi gerektiren bir meslektir. Öğretmenin mesleki yeterlikleri, mesleki becerisi, yönetim becerisi, kişisel özellikleri, iletişim becerisi, tutumu, motivasyonu, mesleğe yönelik inancı öğretim sürecinde bir bütün olarak değerlendirilmesi gerekir (Yeşilyurt, 2011, s. 72).

Öğretmenlik mesleği, eğitim fakültesinde lisans eğitimi kapsamında verilen dersler ile öğretmen adaylarına kazandırılmaya çalışılır. Ayrıca eğitim fakültesi bölümü mezunu olmayanların öğretmen olmasını sağlamak amaciyla pedagojik formasyon eğitimi sertifika programı ile eğitimler yürütülmektedir (Demircioğlu ve Özdemir, 2014, s. 111). Öğretmen adayları bu özelliklerin ne kadar fazlasına sahip olurlarsa başarıları da bir o kadar artacaktır. Bahsedilen özelliklerin bazıları doğuştan gelmekte iken bazıları da öğrenme ile gerçekleşmekte veya geliştirilebilmektedir. Öğretmenler ve öğretmen adayları üzerine yapılan çalışmalara bakıldığında bazı araştırmalarda tek başına öğretmenlik mesleğine ilişkin tutumlarının incelendiğini (Kartal ve Afacan, 2012; Özkan, 2012; Polat, 2013; Eraslan ve Çakıcı, 2011). Bazılarında öğretmenlik mesleğine yönelik özyeterlik inançlarının incelendiğini (Kahyaoğlu ve Yaygın, 2007; Özdemir, 2008; Süral ve Sarıtaş, 2015; Elkatmış, Demirbaş ve Ertuğrul, 2013 ). Bazılarında ise öğretmen adaylarının motivasyonları (Altınkurt, Yılmaz ve Erol, 2014) ile ilgili çalışmalar yapıldığ tespit edilmiştir. 
Pedagojik Formasyon ve eğitim fakültesindeki öğretmen adaylarına yönelik araştırmalar sınırlı sayıda olduğu için bu çalışma önem arz etmektedir. Bu bağlamda bu çalışma, eğitim fakültesindeki öğretmen adayları ile pedagojik formasyon eğitimi alan öğretmen adaylarının öğretmenlik mesleğinde özyeterliğin tutum ve motivasyona etkisini irdelemek amacıyla hazırlanmıştır.

Çalışmanın amaçlarına ulaşmak için, ilk olarak özyeterlik, motivasyon ve tutum kavramlarının açıklamaları üzerinde durulmuştur. Devamında araştırmanın amaçlarına uygun olarak eğitim fakültesi 4. sınıftaki öğretmen adayları ile pedagojik formasyon eğitimi almakta olan öğretmen adaylarının öğretmenlik mesleğinde öz yeterliğin tutum ve motivasyona etkisini ortaya koymak üzere bir model oluşturularak araştırmanın yöntem ve bulguları ayrıntılı bir şekilde açılanmıştır. Takip eden bölümde öğrencilerin özyeterlik, motivasyon ve tutumlarına yönelik analizler gerçekleştirilmiştir. Elde edilen sonuçların yorumlanıp önerilerin sunulması ile çalışma son bulmuştur.

\section{1. Özyeterlik}

Özyeterlik, Albert Bandura'nın Sosyal Öğrenme Teorisi'nin temel kavramlarında belirleyici bir etkendir. Sosyal Bilişsel Teori büyük bir dizi unsuru içerir. Bu unsurlar köklü bilişsel, sosyal ve davranışsal becerilerin düzenleyicileri ve motivatörleri olarak görev yaparlar. Sosyal Bilişsel Teori ile özyeterlik bileşkesi arasında ayrım yapmak önemlidir. $\mathrm{Bu}$ durum teorideki diğer belirleyiciler ile insan düşüncesini, motivasyonlarını ve eylemlerini yönetmeye yardımcı olur. Özyeterlik, kişinin belli bir performansı gerçekleştirmek için sahip olduğu yeteneklerini düzenlemesi ve yürütme sürecindeki eylemelere ulaşabilme çabasıdır (Bandura, 1997, s. 34). Bir başka tanımlamaya göre ise, bireyin gelecekte karşılaşabileceği zorlukların üstesinden ne derece etkin gelebileceğine ilişkin inancıdır (Elkatmış vd., 2013, s. 42).

Günümüzde meslek tanımlamaları yapılırken bu meslekleri yapmak için gerekli kişilik özellikleri de belirlenmektedir. Kişilerin yapacakları mesleğin gerektirdiği kişilik özelliklerine sahip olmaları gerekmektedir. Eğitimin en önemli yapı taşlarından biri olan öğretmenlerin, öğretmenlik mesleğinin gerektirdiği kişilik özelliklerine sahip olması gerekmektedir (Yeşilyurt, 2011, s. 72).

Özyeterlik kavramı, öğretmen açısından ele alındığında, öğretmenlik mesleğinde sahip olunması gereken bilgi, beceri ve tutumlar akla gelmektedir. Bu bağlamda öğretmen özyeterliği, öğretmenin etkin ve başarılı olmasında etkili olan önemli bir kavramdır. Fakat öğretmen özyeterliğinin, öğretmen etkililiği veya başarılı öğretim ile aynı anlama geldiğini söylemek pek doğru olmamaktadır. Çünkü okuyucular şöyle bir mantıksal çıkarım hatası yapabilirler. "Öğretmen Yeterliliği” “Öğretmen Etkisi” ile aynıdır veya başarılı öğretimi bu nedenle öğretmen yeterliliği teriminden kaçınmak önemlidir. Bunun yerine öğretmenin yeterlik alg1sı, yeterlik değerlendirmesi, yeterlik hissi, algılanmış yeterlik veya yeterlik inanışlarından bahsetmek gerekir. Bunların hepsi bir görevi yerine getirme becerilerindeki değerlendirmeyi çağrıştırır (Goddard vd., 2004, s. 4).

Özyeterlik, davranış bilimleri ve eğitim alanında çalışan birçok araştırmacı tarafından önemli bulunmuş ve son yıllarda bu alanda pek çok araştırma yapıllmıştır. 
Pedagojik formasyon eğitimi ve eğitim fakültesindeki öğretmen adayları bağlamında literatürde bazı çalışmalar yapıldığı görülmektedir. Özyeterlik algılarını belirlemeye yönelik sınırlı sayıda akademik çalışmada ise pedagojik formasyon eğitimi alan öğretmen adaylarının öz-yeterlik algılarını bazı değişkenler göre farklılık gösterip göstermediğini tespit etmek amacıyla incelemeler yapılmıştır (Uysal ve Kösemen, 2013; Ilgaz vd., 2013; Elkatmış vd., 2013). Çalışmalarda genel olarak öğretmenlerin ya da öğretmen adaylarının belirli bir problem ile karşı karşıya geldiklerinde problemin üstesinden gelip gelemeyecekleri konusu tartışılmıştır (Özdemir, 2008, s. 279).

Özyeterlik, kişinin kendi bilgi ve becerilerine güvenmesine karşılık gelmektedir. Bir durumla baş edebilmede yeterli becerileri olan, ancak özyeterliği düşük seviyede olan birey, söz konusu becerilerini harekete geçiremiyor demektir (Yıldırım ve İlhan, 2010, s. 2). Buna karşılık özyeterliği yüksek olan kişilerin zorluklar karşısında daha güçlü ve dayanıklı oldukları daha az stres ile daha yüksek başarı elde ettikleri gözlemlenmiştir (Kurbanoğlu, 2004, s. 139).

Öz-yeterliği yüksek olan kişiler; karmaşık olaylarla baş edebilir, sorunlar karşısında çözüm odaklıdırlar, cesaret ve inancı yüksek olduğu için başarıları da yüksek seviyededir, kendine olan güvenleri fazladır. Öz-yeterliği düşük olan kişilerde ise; karmaşık olaylar ile baş edebilmesi zordur, sorunlar karşında genelde kendilerini güçsüz ve savunmasız olarak görürler, başarıyı elde edebilecekleri konusunda kendilerine olan güvenleri azdır, genelde mutsuz, umutsuz ve çaresizlik içerisindedirler (Yenilmez ve Kakmac1, 2008, s. 4-5).

\section{Motivasyon}

Motivasyon kavramı ingilizce "motivation", Latince "movere" kelimesinden türetilmiştir(Adair, 2003, s. 9; akt. Uyan). Harekete geçirme anlamına gelmektedir (Arslan vd., 2014, s. 114). "Kişilerin belirli bir amacı gerçekleştirmek için arzu ve istekleri ile davranmaları " biçiminde tanımlanabilir. Bireylerin arzuları, istekleri, amaçları ve ihtiyaçları doğrultusunda gelişen bir kavramdır (Koçel, 1995, s. 382). Bir başka tanıma göre ise motivasyon, bir amaca ulaşma doğrultusundaki çabaya ilişkin kararlılık, yoğunluk ve istikamettir (Robbins ve Judge, 2015, s. 204). Yoğunluk, bir kişinin amacına ulaşabilmek için ne kadar çaba gösterdiği ile ilgilidir. Bu çaba organizasyonun faydası doğrultusunda anlamlandırılamadığı sürece yüksek düzeyli çaba, düşük düzeyli performans ile sonuçlanacaktır. Bu bağlamda örgütte çabanın kalitesi yoğunluğu kadar önem arz etmektedir. Son olarak motivasyonun kararlılık boyutu da vardır. Kararlılık, bir çabayı ne kadar devam ettirip ne kadar koruyabileceğine ilişkindir. İnsan ihtiyaçları sonsuz ve sinırsızdır; bu sebeple insan daha fazla nasıl motive edilebilirim diye hazır durumda beklemektedir. Bir başka ifade ile motivasyonun kaynağını ihtiyaçlar oluşturmaktadır (Durmuş, 2016, s. 8 ).

İnsanlar sosyal bir çevrede yaşar. Bu çevre içerisinde birçok uyaranla karşı karşıya kalır. Bu uyaranların şiddeti, kişinin ilgisi, duyu organlarının algılama düzeyi gibi birçok faktörün etkisiyle uyaranlar beyin tarafından algılanır veya algılanmaz. Eğer beyinde pozitif bir alg1 oluşursa kişi motive olmuş olur. Negatif bir alg1 oluşursa motivasyon olmaz kişi strese girer. Streste kişinin her yönüyle performansının 
düşmesine neden olur (Önen ve Tüzün, 2005, s. 21). Motivasyonun iki önemli özelliği bulunmaktadır: Motivasyon bireysel bir olaydır. Birisini motive eden bir olay bir başkasını motive etmeyebilir. İkincisi motivasyon sadece insan davranışlarında gözlemlenebilen bir olaydır (Koçel, 1995, s. 383).

Motivasyon literatürde iki şekilde incelenmektedir. İç motivasyon, bireyin kendi inançlarının önemini vurgulamaktadır (Zimmerman, 2000, s. 89). Dış motivasyon ise, dıştan sağlanan kontrol anlamına gelmektedir (Ryan ve Deci, 2000, s. 54). İçsel motivasyon bizim ihtiyaçlarımızı, zevklerimizi, inançlarımızı, hedeflerimizi içermektedir. Bizi asıl motive eden ve harekete geçirecek olan motivasyondur. İkinci olarak dışsal (dış) motivasyon ise dişarıdan gelen motivasyon faktörleridir. Bizim dışımızda gerçekleşen, çevreden gelen ödüllendirme, ceza, ya da pekiştirme vasıtasıyla onların ihtiyaçlarına yanıt verme amacı güden faktörlerdir (Durmuş, 2016, s. 8).

Motivasyonun, geleceğin şekillendirilmesi ile ilgili bir kavram olması bakımından, eğitim sisteminin niteliğinin arttırılmasında önemli bir rolü vardır (Evans, 2000, s. 173). İnsanları motive eden faktörler doğru tespit edilirse, iyi anlaşılırsa insanlar o derece etkin şekilde motive olurlar. Motivasyonunun temeli gereksinimlerin karşılanmasına yöneliktir (Hanks, 1999, s. 139).

Literatürde motivasyon ile ilgili eğitim fakültesinde öğrenim gören pedagojik formasyon öğretmen adayları ve eğitim fakültesinde öğrenim gören öğretmen adayları ile ilgili bazı çalışmalar mevcuttur. Altınkurt, Yılmaz ve Erol (2014), pedagojik formasyon öğrencilerinin öğretmenlik mesleğine yönelik motivasyonları üzerine yapmış olduğu çalışmada pedagojik formasyon programı öğrencilerinin öğretmenlik mesleğine yönelik motivasyonları daha yüksek seviyede çıkmıştır. Alemdağ vd. (2014)' nin beden eğitimi öğretmeni adaylarının akademik motivasyon ve akademik öz yeterlikleri akademik motivasyon düzeyinin cinsiyet değişkeni ve sınıf değişkenine göre farklılaştı̆̆ı görülmüştür. Gençay ve Gençay (2007)' in çalışmasında, sınıflara göre öğretmenlik mesleğine yönelik motivasyon düzeylerinin farklılaştığı tespit edilmiştir.

\section{Tutum}

Tutum, davranışın öncü bir uyarısı ile bireyi davranışa hazırlayan bir bilgi birikimidir. Bu bağlamda tutum, bireyin bir uyaran ile karşı karşıya gelmeden onun etkisi altında kalmadan bir kişi ya da nesne hakkında tepki göstermesidir, denilebilir (Erdoğan, 2007, s. 153-154 ). Bir başka tanıma göre tutum, "Bireyin kendi dünyasının bir yönü ile ilgili olarak, belirli değer yargılarına ve inançlarına bağlı olarak ortaya çıkan coşku ve tanıma süreçleridir" (Eren, 2012, s. 173-174). Birey, sosyal bir çevrede ve karmaşık bir alemde kendisi için sınırlı sayıda olabilecek bazı kişi, kurum ve nesneler ile sürekli karşı karşıya gelmektedir. Karşılaştığı bu uyaranlardan sürekli olarak etkilenmekte, onlardan bazı bilgiler edinmekte ve edindiği bilgiler ile inanç ve düşünceleri de şekillenmektedir. Kişi bu şekilde çevresinden almış olduğu uyaranları bütünleştirmekte ve zihinsel sisteminde saklamaktadır. Tekrar aynı kişi ve olgularla karşılaştığı zaman, saklamış olduğu bu düşünce demetini gün yüzüne çıkarması bireyin tutumlarını oluşturacaktır (Erdoğan, 2007, s. 535). 
Tutumu, bireyin çevresinden algıladıkları doğrultusunda oluşturduğu duygu, düşünce, inanç, his olarak tanımlayabilmek mümkündür. İnsanlar çevrelerinde ilk karşılaştıkları kişi veya nesnelere karşı tutum oluşturmazlar, önce inanç ve değerler oluştururlar. Eğer tekrarlı bir şekilde bu uyaranlar devam ederse işte o zaman tutum oluşmuş demektir (Güney, 2000, s. 251). Tutumları tam olarak anlamlandırabilmek için onların temel özelliklerini ya da unsurlarını da göz önünde bulundurmak gerekmektedir. Tutumların üç temel unsuru bulunmaktadır bu temel unsurlar davranışın önemli bir öngörü olarak görülen psikolojik bir değişkendir. Birincisi, bilişsel unsur, bireyin çevresindeki varlık ve nesneler hakkında sahip olduğu tüm bilgilerdir. İkincisi, duygusal unsur, bireyin kişiye, gruba veya nesneye karşı duygusal ya da hislere yönelik bölümüdür. Örneğin; Heyecanlanma, üzülme, sevinme gibi. Üçüncü olarak, davranışsal unsur, birey veya nesneye karşı belirli bir biçimde davranma niyetini açıklar) Bu belirlenen unsurlar tutumlar ile davranışlar arasındaki mevcut ilişkiyi anlamaya yöneliktir ve yapının ayrılmaz parçaları olarak birçok yönden birbirleriyle yakından ilişkili kolayca soyutlanamayan, kesin çizgilerle ayırmanın zor olduğu unsurlardır (Robbins ve Judge, 2015, s. 72-73).

İnsanlar doğuştan tutumlara sahip değillerdir, zaman içerisinde değişme ve gelişme göstererek şekillenirler (Kağıtçıbaşı, 1988, s. 100). İnsanlar değişen çevre koşullarına ayak uydurmaya çalışan bireylerinde tutumlarında değişimler gözlemlemek mümkündür (Eren, 2012, s. 174-180 ). Bu değişimler çoğu zaman gözlemlenemeyen, saklı değişkenler olarak davranış şekillerinden (ses, tavır, jest, mimik...gibi) çıkartılabilmektedir (İnceoğlu, 2004, s. 25 ).

Öğretmenlik mesleği; bilgi ve becerilerinin yanı sıra, aynı zamanda tutum ve düzenli alışkanlıklar gerektiren bir meslektir. "Bu nedenle okullarda öğrenim gören ögrretmen adaylarının, meslekle ilgili değer ve tutum kazanmaları da, en az bilgi ve beceri kadar gereklidir" (Çeliköz ve Çetin, 2004, s. 137). Öğretmen adayları mesleklerini icra etmeye başladıklarında geleceğini şekillendirecek oldukları öğrenciler üzerinde tutum ve davranışlarının önemli bir etkiye sahip olacağı yadsınamaz bir gerçektir (Aydın ve Sağlam, 2012, s. 262). Öğretmen adaylarının sergiledikleri tutumlar, mesleki davranışlarını yönlendirmede oldukça etkili olmaktadır (Özkan, 2012, s. 32). Öğretmen adaylarının öğretmenlik mesleğine karşı geliştirmiş oldukları bilişsel, duygusal ve davranışsal tutumlar onların meslekte başarıya ulaşmalarında etkili olmaktadır. Bu bağlamda eğitim kalitesini arttırmak ve öğrencilere iyi bir rol model olabilmek ve geleceklerine 1şı tutabilmek için öğretmen adaylarının mesleğe karşı olumlu tutum geliştirmesi gerekmektedir (Recepoğlu, 2013, s. 313).

Yapılan bazı araştırmalarda öğretmen adaylarının öğretmenlik mesleğine yönelik tutumları incelenmiştir (Çapa ve Çil, 2000; Yüksel, 2004; Şimşek, 2005; Acat vd. 2005; Sayın, 2005; Kaya ve Büyükkasap, 2005; Bulut ve Doğar, 2006; Çakır, Kan ve Sünbül, 2006; Gömleksiz vd., 2006; Gürbüz ve Kışoğlu, 2007; Terzi ve Tezci,2007; Çetinkaya, 2009; Başbay vd., 2009; Kartal, 2009; Eraslan ve Çakıcı, 2011). 


\section{Alan Çalışması}

\subsection{Alan Çalışmasının Amacı}

Bu araştırma Akdeniz Üniversitesi Eğitim Fakültesi 4. sınıfta öğrenim görmekte olan öğretmen adayları ile Eğitim Fakültesinde Pedagojik Formasyon eğitimi almakta olan öğretmen adaylarının özyeterliğin tutum ve motivasyon üzerine etkisini irdelemek amacıyla yapılmıştır.

\section{2. Çalışmanın Hipotezleri}

$\mathrm{H}_{1}$ : Özyeterlik boyutlarından başlamanın motivasyonun başarı boyutu üzerine bir etkisi vardır.

$\mathrm{H}_{2}$ : Özyeterlik boyutlarından yılmamanın motivasyonun güç boyutu üzerine bir etkisi vardır.

$\mathrm{H}_{3}$ : Özyeterlik boyutlarından sürdürmenin motivasyonun ilişki boyutu üzerine bir etkisi vardır.

$\mathrm{H}_{4}$ : Özyeterlik boyutlarından başlamanın tutum üzerine bir etkisi vardır.

$\mathrm{H}_{5}$ Özyeterlik boyutlarından yılmamanın tutum üzerine bir etkisi vardır.

$\mathrm{H}_{6:}$ Özyeterlik boyutlarından sürdürmenin tutum üzerine bir etkisi vardır.

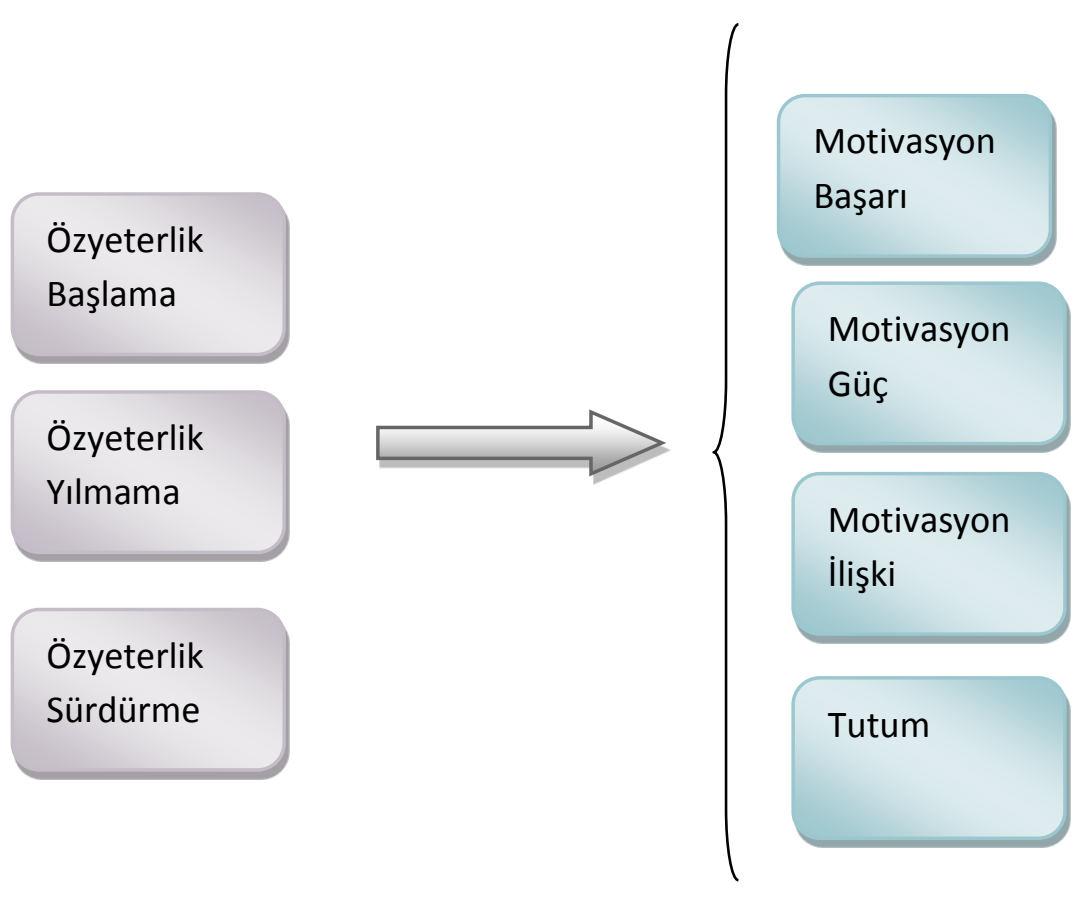

Şekil 1. Araştırma Modeli 


\section{3. Çalışmanın Yöntemi ve Veri Toplama Aracı}

Çalışmanın temel aldığı nicel araştırma yönteminin veri toplama aracı olarak anket formu kullanılmıştır. Veriler tesadüfi örneklem yöntemi ile toplanmıştır. Veri toplama aracı olarak kullanılan soru formunda demografik sorular, motivasyon, tutum ve özyeterlik ölçekleri kullanılmıştır. Özyeterlik Becerileri Envanteri ölçeğinin 23 maddelik özgün formu Sherer vd., (1982) tarafından geliştirilmiştir. Özgün haliyle 14 dereceli olan ölçeğin son hali beş dereceli Likert tipi bir ölçeğe çevrilmiştir (Sherer ve Adams 1983). Yıldırım ve İlhan (2010) tarafından son hali verilen Likert tipi 17 sorudan oluşan bir envanterdir. Özyeterlik beceri envanteri; başlama, yılmama, sürdürme çabası ve ısrar alt boyutlarından oluşmaktadır. Öğretmenliğe İlişkin Tutum Ölçeği 38 maddeden Tezbaşaran (1996) yılında çevrilmiş Erkuş vd. (2000) tarafından son hali verilmiştir. Motivasyon anketi McCleland' in Güdüleme testidir. Anket sorularında 5' Likert ölçeği kullanılmıştır. Anket soruları Güldane Karslığlunun (2011) yüksek lisans tezinden alınmış olup Kuş (2015) tarafından geliştirilmiştir. Motivasyon beceri envanteri başarı, güç ve ilişki alt boyutlarından oluşmuştur. Ölçekler 5'li Likert tipi derecelendirmeyle düzenlenmiş ve araştırmaya katılan öğrencilerden her maddeyi okuyup; "kesinlikle katılıyorum 5", "katılıyorum 4", “az katılıyorum 3", "katılmiyorum 2" ve "kesinlikle katılmıyorum 1" seçeneklerinden birini işaretlenmesi istenmiştir. 2015-2016 yılı Bahar döneminde Akdeniz Üniversitesi Sosyal Bilimler Enstitüsünden gerekli yazılı ve sözlü izinler alındıktan sonra araştırmaya katılan öğrencilere çalışmanın amacı açılanarak, gönüllü katılmaları istenmiştir. Soru formları öğrencilere sınıf ortamında uygulanmıştır. Analiz sürecinde soru formları önce gözden geçirilmiş ve eksik işaretleme yapan katılımcıların formları araştırma dışı bırakılmış; eksiksiz olduğu tespit edilen toplam 400 adet anket formu analize dâhil edilmiştir.

\subsection{Evren ve Örneklem}

Araştırma evrenini, 2015-2016 Eğitim-Öğretim yılında Akdeniz Üniversitesinde öğrenim gören öğretmen adayları oluşturmaktadır. Araştırmanın örneklemini Eğitim Fakültesi 4. sınıfta öğrenim gören öğretmen adayları ile Eğitim Fakültesinde Pedagojik Formasyon eğitimi alan öğretmen adayları olarak belirlenmiş, öğretmen adaylarına sınıf ortamında uygulanan soru formlarından eksiksiz doldurulan 400 anket analizlere dâhil edilmiştir.

\subsection{Analizler ve Bulgular}

Verilerin analizleri için SPSS 22.0 paket programı kullanılmıştır. Elde edilen verilerin normal dağılıp dağılmadığını tespit etmek amacıyla, Kolmogorov Simirnov testi uygulanmış ve test sonucunda verilerin normal dağılım gösterdiği saptanmıştır. Veriler normal dağılım gösterdiği için parametrik testler uygulanmıştır. Öğretmen adaylarının demografik değişkenlerini saptamak amacıyla frekans ve yüzde analizlerinden yararlanılmıştır. Ankette yer alan ifadeler açıklayıcı faktör analizine tabi tutulmuştur. Verilerin faktör analizine uygunluk gösterip göstermediği Kaiser-Meyer-Olkin (KMO) Katsayısı ve Barlett Sphericity Testi ile test edilmiştir. Elde edilen faktörler arasındaki ilişkileri ortaya koymak maksadıyla Pearson korelasyon analizi gerçekleştirilmiştir. Özyeterlik, Motivasyon ve Tutum alt 
boyutları arasında bir etki olup olmadığını saptamak için ise regresyon analizinden yararlanılmıştır. Araştırmada kullanılan ölçeklerin, güvenilirlik analizleri sonucunda motivasyon ölçeğinin cronbach's alfa değeri 0,90, tutum ölçeğinin cronbach's alfa değeri ise 0,93 , özyeterlik ölçeğinin cronbach' s alfa değeri 0,82 bulunmuştur.

Tablo 1. Demografik Özellikler

\begin{tabular}{|c|c|c|}
\hline Cinsiyet & $\mathbf{N}$ & $\%$ \\
\hline Kadın & 264 & 66,0 \\
\hline Erkek & 136 & 34,0 \\
\hline \multicolumn{3}{|l|}{ Yaş } \\
\hline $18-25$ & 301 & 75,8 \\
\hline $26-33$ & 75 & 18,9 \\
\hline $34-42+$ & 24 & 5,3 \\
\hline \multicolumn{3}{|l|}{ Medeni Durum } \\
\hline Evli & 61 & 15,4 \\
\hline Bekâr & 339 & 84,6 \\
\hline \multicolumn{3}{|l|}{ Öğrencilerin Okuduğu Bölüm } \\
\hline İlköğretim Matematik Öğretmenliği & 47 & 26,0 \\
\hline Okul Öncesi Öğretmenliği & 50 & 27,6 \\
\hline Türkçe Öğretmenliği & 10 & 5,5 \\
\hline İngilizce Öğretmenliği & 13 & 7,2 \\
\hline Sınıf Öğretmenliği & 12 & 6,0 \\
\hline Sosyal Bilgiler Öğretmenliği & 32 & 17,7 \\
\hline Fen Bilgisi Öğretmenliği & 14 & 7,7 \\
\hline İlahiyat & 3 & 1,7 \\
\hline \multicolumn{3}{|l|}{ Öğrencilerin Mezun Olduğu Bölüm } \\
\hline Tarih & 63 & 28,8 \\
\hline Matematik & 42 & 19,2 \\
\hline İşletme & 37 & 16,9 \\
\hline Biyoloji & 39 & 17,8 \\
\hline Turizm İşletmeciliğgi & 38 & 17,3 \\
\hline \multicolumn{3}{|l|}{ Eğitim Türü } \\
\hline Pedagojik Formasyon & 219 & 54,3 \\
\hline Eğitim Fakültesi & 181 & 45,7 \\
\hline
\end{tabular}


Tablo 1 incelendiğinde, araştırmaya katılan öğretmen adaylarının \% 66,0' sının kadın öğretmen adaylarından oluştuğu dikkat çekmektedir. Araştırmaya katılan öğrencilerin büyük çoğunluğu (\%75,8)' i 18-25 yaş arasındadır. Katılımcıları medeni durumlarına bakıldığında \% 84, 6’ sının bekâr olduğu bulgusuna ulaşılmıştır. Eğitim fakültesinde öğrenim gören öğretmen adaylarının \%27,6'sının okuduğu bölüm olarak Okul Öncesi Öğretmenliği işaretlediği bulgusuna ulaşılırken, \%28,8'inin Pedagojik Formasyon eğitimi alan öğretmen adaylarının Tarih bölümünde mezun olduğu dikkat çekmektedir. Araştırmaya katılan öğretmen adaylarının \%54,3' ünü Pedagojik Formasyon Eğitimi alanlar oluşturmaktadır.

Tablo 2. Özyeterlik ve Motivasyon Boyutları ile Tutumun Ortalama ve Standart Sapma

\begin{tabular}{lccc}
\hline & $\mathbf{N}$ & Ortalama & Standart Sapma \\
\hline Özyeterlik Boyutları & & & \\
\hline Başlama & 400 & &, 72 \\
Yılmama & & 3,88 &, 78 \\
Sürdürme & & 3,75 &, 86 \\
Motivasyon Boyutları & 400 & 3,79 &, 65 \\
\hline Başarı & &, 68 \\
Güç & & 4,10 &, 62 \\
İlişki & 4,02 &, 74 \\
Tutum & & 4,01 & \\
\hline
\end{tabular}

Tablo 2 incelendiğinde, araştırmaya katılan öğretmen adaylarının verdikleri cevaplara ilişkin ortalama değerlerden özyeterlik envanteri alt boyutlarında en yüksek ortalamaya başlama $(3,88)$ ve en düşük ortalamaya yılmama $(3,75)$ alt boyutunda rastlandığı görülmektedir. Araştırmaya katılan öğrencilerin verdikleri cevaplara ilişkin ortalama değerlerden motivasyon becerileri alt boyutlarında en yüksek ortalamaya başarı alt boyutunda $(4,10)$ ve en düşük ortalamaya ilişki alt boyutunda rastlandığı tespit edilmiştir. Araştırmaya katılan öğrencilerin verdikleri cevaplara ilişkin değerlerden tutum ortalama $(4,33)^{\prime}$ dür.

Tablo 3. Özyeterlik Boyutlarının Motivasyon Başarı Üzerine Etkisi

\begin{tabular}{lccc}
\hline \multicolumn{1}{c}{ Özellikler } & $\begin{array}{c}\text { Standartlaştırılmamış } \\
\text { Beta Katsayısı }\end{array}$ & $\begin{array}{c}\text { Standartlaştırılmış } \\
\text { Beta Katsayısı }\end{array}$ & p değeri \\
\hline Sabit & 2,162 & &, $000^{*}$ \\
Özyeterlik Başlama &, 295 &, 324 &, $000^{*}$ \\
Özyeterlik Yılmama &, 221 &, 262 &, $000^{*}$ \\
Özyeterlik Sürdürme &,- 007 &,- 009 &, 874 \\
\hline
\end{tabular}

$R 2=, 296, \quad F=47,839(0,00),{ }^{*} P<0,01$ 
Pedagojik formasyon eğitimi alan öğrenciler ile Ĕ̆itim Fakültesi 4. Sinıf öğrencilerinin özyeterlik boyutlarına yönelik algılarının motivasyon başarı boyutuna etkisini incelemek maksadıyla faktör analizinden elde edilen üç özyeterlik alt boyutu bağımsız değiş̧ken motivasyon alt boyutlarından başarı bă̆̆mlı değişken şeklinde kullanılarak çok değişkenli doğrusal regresyon analizi gerçekleştirilmiştir. Oluşturulan regresyon modeli Özyeterlik boyutlarından başlama ve yılmama boyutları ile anlamlı bir etkiye sahip olduğu teyit edilirken, sürdürme boyutu ile arasında bir etki olmadığı tespit edilmiştir. $F(3,333)=47,839, P<0,01)$, (H1 Kabul). Bă̆ımsız değişkenler motivasyon başarı boyutunun \%29,6'sını açıklamaktadır. Standart katsayıları sırasıyla özyeterlik başlama boyutu,295 özyeterlik yılmama boyutu,221 ve özyeterlik sürdürme boyutu için -,007'dir. Bu sonuçlar özyeterlik başlama boyutunun motivasyon başarı boyutu üzerinde en yüksek etkiye sahipken (,295), bunu sırasıyla yılmama ve sürdürme takip etmektedir.

Tablo 4. Öz yeterlik Boyutlarının Motivasyon İlişki Üzerine Etkisi

\begin{tabular}{lccc}
\hline \multicolumn{1}{c}{ Özellikler } & $\begin{array}{c}\text { Standartlaştırılmamış } \\
\text { Beta Katsayısı }\end{array}$ & $\begin{array}{c}\text { Standartlaştırılmış } \\
\text { Beta Katsayısı }\end{array}$ & p değeri \\
\hline Sabit & 2,514 &, 276 &, $000^{*}$ \\
Özyeterlik Başlama &, 261 &, $001^{*}$ &, $000^{*}$ \\
Özyeterlik Yılmama &, 242 &, $034^{*}$ \\
Özyeterlik Sürdürme &,- 106 &,- 135 & \\
\hline
\end{tabular}

$$
R 2=, 201, \quad F=28,280(0,00),{ }^{*} P<0,01
$$

Pedagojik formasyon eğitimi alan öğrenciler ile Ĕ̆itim Fakültesi 4. Sını öğrencilerinin özyeterlik boyutlarına yönelik algılarının motivasyon başarı boyutuna etkisini incelemek maksadıyla faktör analizinden elde edilen 3 özyeterlik alt boyutu bağımsız değişken motivasyon alt boyutlarından ilişsi bağımlı değişken şeklinde kullanılarak çok değişkenli doğrusal regresyon analizi gerçekleştirilmiştir. Oluşturulan regresyon modeli Özyeterlik boyutlarmın üç boyutu tarafindan anlaml şekilde etkilendiğini teyit etmektedir. $F(3,345)=28,280, P<0,01),\left(\mathrm{H}_{2} \mathrm{Kabul}\right)$. Bağımsız değişkenler motivasyon ilişki boyutunun \%20,1' ini açıklamaktadır. Standart katsayıları sırasıyla özyeterlik başlama boyutu ,261 özyeterlik yılmama boyutu,242 ve özyeterlik sürdürme boyutu için -,106'dir. Bu sonuçlar özyeterlik başlama ve yılmama boyutunun motivasyon ilişki boyutu üzerinde en yüksek etkiye sahip olduğunu göstermektedir. 
Tablo 5. Özyeterlik Boyutlarının Motivasyon Güç Üzerine Etkisi

\begin{tabular}{lccc}
\hline \multicolumn{1}{c}{ Özellikler } & $\begin{array}{c}\text { Standartlaştırılmamış } \\
\text { Beta Katsayısı }\end{array}$ & $\begin{array}{c}\text { Standartlaştırılmış } \\
\text { Beta Katsayısı }\end{array}$ & p değeri \\
\hline Sabit & 2,465 &, 310 &, $000^{*}$ \\
Özyeterlik Başlama &, 267 &, 198 &, $000^{*}$ \\
Özyeterlik Yılmama &, 158 &,- 027 &, 666 \\
Özyeterlik Sürdürme &,- 020 & & \\
\hline
\end{tabular}

$R 2=, 213, \quad F=30,864(0,00),{ }^{*} P<0,01$

Pedagojik formasyon eğitimi alan öğrenciler ile Ĕğitim Fakültesi 4. Sını öğrencilerinin özyeterlik boyutlarına yönelik algılarının motivasyon başar boyutuna etkisini incelemek maksadıyla faktör analizinden elde edilen 3 özyeterlik alt boyutu bă̆ımsız değişken motivasyon alt boyutlarından güç bağıml değişken şeklinde kullanılarak çok değişkenli doğrusal regresyon analizi gerçekleştirilmiştir. Oluşturulan regresyon modelinde Özyeterlik boyutlarından başlama ve yılmama boyutları ile anlamlı bir etkiye sahip olduğu teyit edilirken, sürdürme boyutu ile arasında bir etki olmadiğı tespit edilmiştir. $F(3,343)=30,864, P<0,01),\left(\mathrm{H}_{3} \mathrm{Kabul}\right)$. Bağımsız değişkenler motivasyan güç boyutunun \%21,3' ünü açıklamaktadır Standart katsayıları sırasıyla özyeterlik başlama boyutu,267özyeterlik yılmama boyutu, 158 ve özyeterlik sürdürme boyutu için -,020'dir. Bu sonuçlar özyeterlik başlama boyutunun motivasyon güç boyutu üzerinde en yüksek etkiye sahip olduğunu göstermektedir.

Tablo 6. Öz yeterlik Boyutlarının Tutum Üzerine Etkisi

\begin{tabular}{lccc}
\hline \multicolumn{1}{c}{ Özellikler } & $\begin{array}{c}\text { Standartlaştırılmamış } \\
\text { Beta Katsayısı }\end{array}$ & $\begin{array}{c}\text { Standartlaştırılmış } \\
\text { Beta Katsayısı }\end{array}$ & p değeri \\
\hline Sabit & 3,414 &, 162 &, $000^{*}$ \\
Özyeterlik Başlama &, 163 &, 012 &, 878 \\
Özyeterlik Yılmama &, 011 &, 080 &, 255 \\
Özyeterlik Sürdürme &, 068 & & \\
\hline
\end{tabular}

$R 2=, 054, \quad F=6,333(0,00),{ }^{*} P<0,01$ 
Pedagojik formasyon eğitimi alan öğrenciler ile Ĕ̆itim Fakültesi 4. Sinıf öğrencilerinin özyeterlik boyutlarına yönelik algılarının motivasyon başarı boyutuna etkisini incelemek maksadıyla faktör analizinden elde edilen 3 özyeterlik alt boyutu bă̆ımsız değişken tutum ise bağıml değişken şeklinde kullanılarak çok değişkenli doğrusal regresyon analizi gerçekleştirilmiştir. Oluşturulan regresyon modelinde Öz yeterlik boyutları ile anlamlı bir etkiye sahip olmadığ tespit edilmiştir. $F(3,333)=6,333, P<0,01)$. $\left(H_{4}, H_{5}, H_{6} R e d\right)$. Bağgrmsız değişkenler tutum değiş̧keninin \%5,4' ünü açıklamaktadır. Standart katsayıları sırasıyla özyeterlik başlama boyutu,163 özyeterlik yılmama boyutu, 011 ve özyeterlik sürdürme boyutu için ,068'dir. Bu sonuçlar özyeterlik başlama boyutunun tutum üzerinde en yüksek etkiye sahip olduğunu göstermektedir.

\section{Sonuç Ve Öneri}

$\mathrm{Bu}$ çalışma eğitim fakültesi ile pedagojik formasyon eğitimi alan öğretmen adaylarının öğretmenlik mesleğinde öz yeterliğin tutum ve motivasyona etkisini irdelemek amacıyla hazırlanmıştır.

Öğretmen adaylarının niteliğini arttırıp başarıya ulaştırabilecek faktörlerden birisi kendini mesleki anlamda yeterli düzeyde görmesidir. Niteliğini arttıramayan öğretmen adaylarının başarıya elde etmesi zordur. Başarıyı elde edemeyen öğretmen adayının tutum ve davranışlarında da birtakım olumsuzlukları beraberinde getirecektir. Bu olumsuzluklar öğrencinin etkililik ve verimliliğini azaltacağı gibi öğretmenlerin motivasyonlarında azalmalara neden olacaktır. Bu bağlamda bu üç kavram birlikte ele alındığında öğrenci ve öğretmen kalitesi ve başarısı için önem arz etmektedir.

Araştırma bulgularına göre, özyeterlik ölçeğinin alt boyutları (başlama, yılmama, sürdürme) ile motivasyon ölçeğinin alt boyutları (başarı, ilişki, güç) üzerinde bir etkiye sahipken tutum üzerinde bir etkiye sahip olmadığı saptanmıştır.

İlgili literatür incelendiğinde, Polat (2013) Pedagojik formasyon eğitimi alan öğrencilerinin mesleğe yönelik tutumları Eğitim Fakültesi öğrencilerinden daha yüksek çıkmıştır ve bu bulgular bu çalışma ile benzerlik göstermektedir. Gürbüz ve Kışoğlu'nun (2007) eğitim fakültesi öğrencilerinin mesleğe yönelik tutumları ile formasyon öğrencilerinin tutumları arasında anlamlı bir farklılık gözlemlemediği görülmektedir. Bahçeci vd.'lerinin (2015) çalışmasında fen edebiyat fakültesinden mezun olup pedagojik formasyon eğitimi alan öğretmen adaylarının öğretmenlik mesleğine karşı tutumlarının, eğitim fakültesi son sınıfta öğrenim gören öğretmen adaylarının mesleğe karşı tutumlarının daha yüksek seviyede olduğu sonucuna ulaşılmıştır. Bu sonuçlar da çalışmayı destekler niteliktedir. Elkatmış vd. (2013) Eğitim fakültesi öğrencileri ile fen edebiyat fakültesi öğrencilerinde özyeterlik inançları arasında bir farklılık olmadığını tespit etmiştir. Çocuk vd., (2015) yaptığı çalışmada pedagojik formasyon öğrencilerinin öğretmenliğe ilişkin özyeterlik ve metaforik algıları incelenmiş ve özyeterlik algılarının pedagojik formasyon öğrencilerinde daha yüksek çıkmıştır (Durmuş, 2016, s. 8). İlgili literatürde motivasyon ile ilgili eğitim fakültesinde öğrenim gören pedagojik formasyon öğretmen adayları ve eğitim fakültesinde öğrenim gören öğretmen adayları ile ilgili bazı çalışmalar mevcuttur. Altınkurt, Yılmaz ve Erol (2014), pedagojik formasyon öğrencilerinin öğretmenlik mesleğine yönelik motivasyonları üzerine yapmış olduğu 
çalışmada pedagojik formasyon eğitimi alan öğrencilerin öğretmenlik mesleğe duydukları motivasyonlarının daha yüksek seviyede çıktığı sonucuna ulaşılmıştır. Bu bulgu bu çalışmayı destekler niteliktedir.

Çalışmadaki bulguların farklılıklar göstermesinde, sosyal ve kültürel etkenler, gelir düzeyi, üniversite koşulları, araştırmanın uygulandığı örneklem alanı, çalışma gruplarının bulunduğu üniversiteden ve çalışmanın yapıldığı zaman farklılıkları gibi faktörlerden kaynaklanmış olabileceği düşünülmektedir.

$\mathrm{Bu}$ araştırma her ne kadar Antalya' da bulunan Akdeniz Üniversitesi Eğitim Fakültesinde gerçekleştirilmiş olsa da birtakım kısıtları da mevcuttur. İlk olarak araştırma kapsamında veriler eğitim fakültesi 4. sinıfta öğrenim gören öğretmen adaylarından toplanmış olmasından dolayı sonuçlar eğitim fakültesinde diğer sınıflarda öğrenim gören öğretmen adaylarının özyeterlik, motivasyon ve tutum düzeylerini tam olarak yansıtmayabilir. Bu sebeple ileriki çalışmaların diğer sınıflarda öğrenim gören öğretmen adaylarını kapsayacak şekilde gerçekleştirilmesi ve aralarında karşılaştırılma yapılması önerilmektedir. Ayrıca fen edebiyat fakültesinde öğrenim görüp pedagojik formasyon eğitimi almayan öğrencilerin mesleğine yönelik özyeterlik, tutum ve motivasyonları incelenebilir. Eğitim fakültelerinde öğrenim gören öğrencilerin özyeterlik, motivasyon ve tutum algılarına ilişkin eksiklikleri dikkate alınarak derslerin çeşitlendirilmesi ile öğretmen adaylarının özyeterlik algılarının yükseltilip motivasyon ve tutumlarında değişiklik sağlanabilir. Öğretmenlik uygulamasının daha aktif bir şekilde yapılması, öğretmen adaylarına ileride kendini adayacakları meslekleriyle ilgili eksiklikleri daha rahat tespit etme fırsatı elde edeceklerdir. Üniversitelerde çeşitli konferanslar, tanıtım ve kariyer günleri düzenlenebilir. Aynı kapsamda yapılacak başka bir çalışma nitel çalışmalar ile desteklenebilir.

\section{KAYNAKÇA}

Adair, J. (2003). Etkili Motivasyon (Çev: Salih Uyan), İstanbul: Babıali Kültür Yayıncılı̆̆ı.

Aydın R. ve Sağlam, G. (2012). Öğretmen Adaylarının Öğretmenlik Mesleğine Yönelik Tutumlarının Belirlenmesi (Mehmet Akif Ersoy Üniversitesi Örneği) Türk Eğitim Bilimleri Dergisi Bahar, 10(2), 257-294.

Bahçeci, B. Yıldırım İ. Kara, K. ve Keskinpalta, P. (2015). Pedagojik Formasyon ve Eğitim Fakültesi Öğrencilerinin Öğretmenlik Mesleğine Yönelik Tutumlarının Karşılaştırılması Erzincan Üniversitesi Eğitim Fakültesi Dergisi, 17(1).

Başbay, M. Ünver G., ve Bümen N.T. ( 2009). Ortaöğretim Alan Öğretmenliği Tezsiz Yüksek Lisans Öğrencilerinin Öğretmenlik Mesleğine Yönelik Tutumları: Boylamsal Bir Çalışma, Kuram ve Uygulamada Eğitim Yönetimi (59), 345-366.

Castetter, B.W. (1986). Administering School Personal, New-York.

Çeliköz, N. ve Çetin, F. (2004). Anadolu Öğretmen Lisesi Öğrencilerinin Öğretmenlik Mesleğine Yönelik Tutumlarını Etkileyen Etmenler. Millî Eğitim Dergisi, 32(162), 136-145. 
Çocuk, H. E., Yokuş, G., ve Tanrıseven, I. (2015). Pedagojik Formasyon Öğrencilerinin Öğretmenliğe İlişkin Özyeterlik ve Metaforik Algıları: Mersin Üniversitesi Örneği Mustafa Kemal Üniversitesi Sosyal Bilimler Enstitüsü Dergisi, 12(32), 373-387.

Demircioğlu, E. ve Özdemir, M. (2014). Fen ve Edebiyat Fakültesi Öğrencilerinin Öğretmenlik Mesleğine Yönelik Tutumlarının Çeşitli Değişkenlere Göre İncelenmesi, Mersin Üniversitesi Eğitim Fakültesi Dergisi, 10(3), 110-122.

Durmuş, H. "Eğitim Yönetiminde Motivasyon Ödüllendirme" www. Hayati durmus.com/GGO/subat_pdf/08.pdf (14.04.2016).

Elkatmış, M. Demirbaş, M. ve Ertuğrul, N. (2013). Eğitim Fakültesi Öğrencileri İle Formasyon Eğitimi Alan Fen Edebiyat Fakültesi Öğrencilerinin Öğretmenlik Mesleğine Yönelik Öz yeterlik İnançları, Pegem Eğitim ve Öğretim Dergisi, 3(3), 41-50.

Eraslan L., ve Çakıcı D. (2011). Pedagojik Formasyon Programı Öğrencilerinin Öğretmenlik Mesleğine Yönelik Tutumları. Kastamonu Eğitim Dergisi, 19(2): 427438.

Erdoğan, İ. (2007). İşletmelerde Davranış, İstanbul: MİAD- Malatyalı İşadamları Derneği Yönetim Yayınları Dizisi 1.

Eren, E. (2012). Örgütsel Davranış ve Yönetim Psikolojisi, İstanbul: Beta Basım Yayım Dağıtım.

Evans, L. (2000). Theeffects Of Educational change On Moral, Jobsatisfaction and motivation. Journal of Educational Change, 1: 173-192.

Gençay, Ö. A. ve Gençay, S. (2007). “Beden Eğitimi Ve Spor Yüksekokulu Öğrencilerinin Öğretmenlik Mesleğine İlişkin Motivasyon Düzeylerinin Bazı Değişkenler Açısından İncelenmesi", Selçuk Üniversitesi Sosyal Bilimler Enstitüsü Dergisi, 17, 241-253.

Gömleksiz, M. N., Oral, B. ve Bulut, İ. (2006). Ortaöğretime Nitelikli Öğretmen Yetiştirmede Tezsiz Yüksek Lisans Uygulaması. Orta Öğretimde Yeniden Yapılanma Sempozyumu 20-22 Aralık 2004 Bildiriler Kitabı içinde, Ankara. 545551.

Güney, S. (2000). Yönetim ve Organizasyon El Kitabı, Ankara: Nobel Yayın Dağıtım.

Gürbüz, H. ve Kışoğlu, M. (2007). Tezsiz Yüksek Lisans Programına Devam Eden Fen Edebiyat Fakültesi Ve Eğitim Fakültesi Öğrencilerinin Öğretmenlik Mesleğine Yönelik Tutumları (Atatürk Üniversitesi Örneği), Erzincan Eğitim Fakültesi Dergisi, 9(2), 71-83.

Hanks, K. (1999). İnsanları Motive Etme Sanatı, İstanbul: Alfa Yayınları.

Arslan, H. Can, N. Dönmez, B. Gülveren, H. Işık, H. Karslı, M.D. Kuran, K. Memişoğlu, S. P. Özabacı,N. Sarıtaş, M. Yiğit, B. ve Yücel, C. (2014). Sınıf Yönetimi. Edit: Mehmet Şişman ve Selahattin Turan, Ankara, Pegem Yayınları.

İnceoğlu, M. (2004). Tutum Alg1 ve İletişim, Ankara: Kesit Dağıtım Limited Şirket. 
Kağıtçıbaşı, Ç. (1988). İnsan ve İnsanlar, Evrim Basım Yayın, İstanbul.

Kartal, S. (2009). Tezsiz Yüksek Lisans Programlarına Devam Eden Öğretmen Adaylarının Öğretmenlik Mesleğine Yönelik Tutumları, Selçuk Üniversitesi Ahmet Keleşoğlu Eğitim Fakültesi Dergisi, (28), 223-239.

Kartal, T. ve Afacan, Ö. (2012). Pedagojik Formasyon Eğitimi Alan Öğretmen Adaylarının Öğretmenlik Mesleğine İlişkin Tutumlarının İncelenmesi, Mehmet Akif Ersoy Üniversitesi Eğitim Fakültesi Dergisi, 12(24): 76-96.

Koçel, T. (1995). İşletme Yöneticiliği, İstanbul: Beta Basım Yayım.

Kurbanoğlu, S.S. ( 2004). Öz-Yeterlik İnancı Ve Bilgi Profesyonelleri İçin Önemi, Bilgi Dünyas1, 5(2), 137-152.

Önen, L. ve Tüzün, B. (2005). Motivasyon, İstanbul: Epsilon Yayınc1lık.

Özkan, H.H. (2012). Öğretmenlik Formasyon Programındaki Öğretmen Adaylarının Öğretmenlik Mesleğine İlişkin Tutumlarının İncelenmesi (SDÜ Örneği)Ahi Evran Üniversitesi Kırşehir Eğitim Fakültesi Dergisi (KEFAD) 13(2).

Özdemir, S.M. (2008). Sınıf Öğretmeni Adaylarının Öğretim Sürecine İlişkin Özyeterlik İnançlarının Çeşitli Değişkenler Açısından İncelenmesi, Kuram ve Uygulamada Eğitim Yöntemi, 54-277-306.

Polat, S. (2013). Pedagojik Formasyon Sertifika Programı ve Eğitim Fakültesi Öğrencilerinin Öğretmenlik Mesleğine Yönelik Tutumlarının İncelenmesi, Eİnternational Journal Of Educational Research 4(2), 48-60.

Recepoğlu, E. (2013). Öğretmen Adaylarının Yaşam Doyumları ile Öğretmenlik Mesleğine İlişkin Tutumları Arasındaki İlişkinin İncelenmesi Hacettepe Üniversitesi Eğitim Fakültesi Dergisi (H. U. Journal of Education) Özel Sayı (1), 311-326.

Robbins, S. ve Judge T. (2015). Örgütsel Davranış (Çev: Prof. Dr. İnci Erdem). Ankara: Nobel Basım Yayın.

Ryan, R. M. ve Deci, E.L. (2000) “Intrinsic and Extrinsic Motivations: Classic Definitions and New Directions", Contemporary Educational Psychology, 25, 54-67.

Sayın, S. (2005). Öğretmen Adaylarının Öğretmenlik Mesleğine Karşı Tutumları Ve Mesleki Benlik Saygılarının İncelenmesi. Eğitim Araştırmaları, 5(19): 271-282.

Şimşek H. (2005). Ortaöğretim Alan Öğretmenliği Tezsiz Yüksek Lisans Programına Devam Eden Öğrencilerin Öğretmenlik Mesleğine Yönelik Tutumları. Yüzüncü Y1l Üniversitesi, Elektronik Eğitim Fakültesi Dergisi, 2(1).

Terzi A.R., ve Tezci E.(2007). Necatibey Eğitim Fakültesi Öğrencilerinin Öğretmenlik Mesleğine İlişkin Tutumları. Kuram ve Uygulamada Eğitim Yönetimi, (52), 593614.

Üstüner, M. (2006). Öğretmenlik Mesleğine Yönelik Tutum Ölçeğinin Geçerlik ve Güvenirlik Çalışması" Kuram ve Uygulamada Eğitim Yönetimi Dergisi, 45. 
Yenilmez, K. ve Kakmacı, Ö. (2008). İlköğretim Matematik Öğretmenliği Bölümü Öğrencilerinin Öz Yeterlilik İnanç Düzeyleri, Eskişehir Osmangazi Üniversitesi Sosyal Bilimler Dergisi, 9(2).

Yeşilyurt, E. (2011). Öğretmen Adaylarının Öğretmenlik Mesleğinin Genel Yeterliklerine Yönelik Yeterlik Algıları, Türk Eğitim Bilimleri Dergisi , 9(1), 71-100.

Yıldırım, F. İlhan İ. Ö. (2010). Genel Özyeterlik Ölçeği Türkçe Formunun Geçerlilik ve Güvenilirlik Çalışması, Türk Psikiyatri Dergisi

Yüksel, S. (2004). Tezsiz Yüksek Lisans Programının Öğrencilerin Öğretmenlik Mesleğine İlişkin Tutumlarına Etkisi, Uludağ Üniversitesi Eğitim Fakültesi Dergisi, XVII(2), 355-379.

Zimmerman, B. J. (2000). "Self-Efficacy: An Essential Motive to Learn”, Contemporary Educational Psychology, 25, 82-91. 